\title{
ANALISIS HIGHER ORDER THINKING SKILLS (HOTS) SISWA KELAS XI PADA MATERI SISTEM PERNAPASAN SMAN PLUS PROVINSI RIAU TAHUN AJARAN
}

\author{
Syarifah Fazira, Suryanti, Sepita Ferazona, Tengku Idris \\ Program Studi Pendidikan Biologi. FKIP. Universitas Islam Riau \\ *Korespondensi Author: syarifahfazira96 @gmail.com
}

\section{INFO ARTIKEL}

Histori Artikel

Received 31 Oktober 2019

Revised 9 Januari 2020

Accepted 17 Januari 2020

Published 23 Januari 2020

Keywords:

Higher Order Thinking Skills, Learning Outcome, Respiratory System

\begin{abstract}
ABSTRAK
Penelitian ini bertujuan untuk menganalisis Higher Order Thinking Skills siswa kelas XI SMAN Plus Prov. Riau dalam menyelesaikan masalah pada soal ulangan harian materi sistem pernapasan. Penelitian dilaksanakan pada tanggal 16 sampai tanggal 23 April 2019. Metode penelitian ini adalah deskriptif. Instrumen yang digunakan dalam pengumpulan data adalah soal Higher Order Thinking Skills pada materi sistem pernapasan dengan kategori C4 (Menganalisis), C5( Mengevaluasi), C6( mencipta) yang dibuat berdasarkan Taksonomi Bloom revisi dan wawancara. Sampel pada penelitian ini adalah seluruh siswa kelas XI SMAN Plus Prov. Riau sebanyak 99 siswa. Hasil penelitian menunjukkan bahwa Higher Order Thinking Skills siswa kelas XI SMAN Plus Prov.Riau dalam kategori sangat rendah dengan persentase $50,74 \%$. 68,29\%, siswa mampu menjawab soal C4 sedangkan untuk soal C5 dan C6 masing-masing sebanyak 33,56\% dan 50,37\%. Dengan demikian dapat disimpulkan bahwa siswa SMAN Plus Prov. Riau Tahun ajaran 2018/2019 memiliki Higher Order Thinking Skills (HOTS) dalam kategori sangat rendah.
\end{abstract}

\begin{abstract}
This Research Aims to analysis the ability of higher order thinking skills (HOTS) of students second grade of SMAN Plus Prov. Riau in solving problem on respiratory system material on daily test problems. The study was conducted on 16 to 23 April 2019. This research method is descriptive. The instrument used to collect the data was a matter of Higher Order Thinking Skills on respiratory system material with categories C4 (Analyze), C5 (Evaluate), C6 (create) created based on Bloom's revised Taxonomy and interviews. The sampel of the reseach is the students of the second grade SMAN Plus Prov. Riau as many as 99 students. Based on data analysis, HOTS of student of the second grade SMAN Plus PROV. RIAU in very low category with the percentage $50,74 \%$. From the three levels of HOTS, $68,29 \%$ of students are able to answer matterof $\mathrm{C} 4$, while for matter of $\mathrm{C} 5$ an $\mathrm{C} 6$ recpectively as $33,56 \%$ and $50,37 \%$. Thus, It can be concluded that the HOTS of Student SMAN Plus Prov. Riau 2018/2019 included in very low category.
\end{abstract}

Copyright (C) 2019 Universitas Negeri Medan. Artikel Open Access dibawah lisensi CCBY-4.0 (https://creativecommons.org/licenses/by/4.0)

\section{How To Cite:}

Fazira, S., Suryanti, Ferazona, S., \& Idris, T. (2019). Analisis Higher Order Thinking Skills (HOTS) Siswa Kelas Xi Pada Materi Sistem Pernapasan Sman Plus Provinsi Riau Tahun Ajaran. Jurnal Pelita Pendidikan, 7(4), 144-152. 


\section{PENDAHULUAN}

Pendidikan terbangun dalam beberapa komponen, yaitu pendidik, peserta didik, tujuan pendidikan, alat pendidikan, dan lingkungan pendidikan. Semua komponen yang membangun sistem pendidikan, saling berkaitan, saling tergantung, dan saling menentukan satu sama lain. Setiap komponen memiliki fungsi yang menunjang tercapainya tujuan pendidikan (Saat, 2015: 1). Pendidikan melalui pembelajaran di sekolah pada abad ke-21 mempunyai paradigma pembelajaran yang menekankan kemampuan berpikir kritis, mampu menghubungkan ilmu dengan dunia nyata, menguasai teknologi informasi, berkomunikasi dan berkolaborasi tidak hanya pada satu disiplin ilmu melainkan dalam beberapa disiplin ilmu ( Afriyanti et al., 2018: 608). Sani dalam Wulandari dan Sholihin (2016: 67-73) menyatakan bahwa pendidikan menjadi kekuatan untuk melakukan perubahan-perubahan sebuah kondisi menjadi lebih baik.

Evaluasi pembelajaran bertujuan untuk mengetahui keefektifan dan efisiensi pembelajaran (Munthe, 2015: 1). Proses pendidikan bukan hanya berpatokan pada nilai, tetapi ada banyak faktor yang membuat berhasil atau tidaknya sebuah program, baik yang menyangkut tentang ujian, materi, metode, media, sumber belajar, lingkungan serta sistem penilaian itu sendiri ( Arifin, 2014: 1314). Evaluasi hasil belajar nantinya akan memberikan gambaran tentang tingkat keberhasilan pembelajaran yang dilakukan, antara lain dalam pencapaian ketuntasan belajar siswa.

Analisis soal merupakan suatu prosedural yang sistematis, yang akan memberikan informasiinformasi yang sangat khusus terhadap butir tes yang kita susun. Analisis soal terutama dapat dilakukan untuk tes objektif. Dengan adanya analisis soal dapat diperoleh informasi tentang kualitas soal sehingga dapat dilakukannya perbaikan (Daryanto, 2012: 177-179).

Menurut Kemendikbud (2017) HOTS memiliki karakteristik seperti mengukur kemampuan berpikir tingkat tinggi, meminimalkan aspek mengingat dan memahami, Berbasis permasalahan kontekstual, Stimulus yang menarik, tidak familiar, dan kebaruaan. Aktivitas HOTS membantu siswa terampil mencari ilmu dalam penalaran induktif dan deduktif untuk memikirkan jawaban atau mengidentifikasi dan mengeksplorasi pemeriksaan ilmiah dari fakta-fakta yang ada (Thitima dan Sumalee dalam Yusmanto et al., 2017: 2). Craig dalam Widiawati et al. (2018: 295) mengutarakan jika masalah pada abad 21 adalah HOTS, sehingga peserta didik harus terlibat dalam pembelajaran atau tugas yang berkaitan dengan berbagai pemecahan masalah, tidak hanya hal-hal yang berhubungan dengan ingatan, hapalan, dan pengulangan.

Penelitian ini bertujuan untuk mengetahui Higher Order Thinking Skills siswa kelas XI pada materi Sistem Pernapasan SMAN Plus Prov. Riau Tahun ajaran 2018/2019.

\section{METODE PENELITIAN}

Penelitian ini merupakan penelitian pengembangan dengan menggunakan model 4D. Melalui 4 tahap pengembangan yaitu define, design, develop and disseminate. Penelitian dilakukan di tahap develop yaitu melihat hasil praktikalitas penuntun praktikum yang dikembangkan baik dari dosen maupun mahasiswa sebagai pengguna. Penelitian memanfaatkan angket sebagai instrument untuk mengumpulkan data dengan 4 pilihan jawaban yaitu sangat setuju, setuju, kurang setuju dan tidak setuju. Angket diberikan kepada 3 orang dosen dan 61 orang mahasiswa Angket dimodifikasi dari Susanti (2019) dengan aspek yang diamati kemudahan dalam penggunaan, meliputi: mudah, diatur, disimpan dan dapat digunakan sewaktu-waktu, waktu yang diperlukan dalam pelaksanaan sebaiknya sangat singkat, cepat dan tepat, mudah diinterpretasikan oleh dosen ahli maupun dosen lain, dan memiliki ekivalensi yang sama, sehingga bisa digunakan sebagai pengganti atau variasi. Analisis praktikalitas ini diolah dengan menggunakan rumus modifikasi dari Riduwan dan Kuncoro (2011).

$$
\% \text { Daya Serap }=\frac{\text { jumlah nilai seluruh siswa }}{\text { jumlah siswa } \mathrm{X} \text { jumlah skor ideal }} \times 100
$$

Untuk mengetahui daya serap HOTS siswa dalam menyelesaikan soal ulangan harian pada materi sistem pernapasan manusia, digunakan kriteria sebagai berikut. 
Tabel 1. Kategori Daya Serap Siswa

\begin{tabular}{clc}
\hline No & Interval Daya Serap (\%) & Kategori Daya Serap \\
\hline 1 & $92-100 \%$ & Sangat tinggi \\
2 & $83-91 \%$ & Tinggi \\
3 & $75-82 \%$ & Sedang \\
4 & $67-74 \%$ & Rendah \\
5 & $<67 \%$ & Sangat rendah \\
\hline
\end{tabular}

Sumber: KKM SMAN Plus Prov. Riau 2018/201

\section{HASIL DAN PEMBAHASAN}

Hasil utama penelitian ini adalah untuk menafsirkan nilai atau skor yang diperoleh melalui perhitungan atas masing-masing tingkat soal pilihan ganda dan essay yang terdiri dari 13 pertanyaan kepada 99 siswa sebagai sampel. Maka untuk mendapatkan persentasenya disesuaikan dengan kriteria yang disajikan dibawah ini.

\section{Analisis Data Soal Ranah Kognitif Tingkat C4 (Menganalisis)}

Hasil yang diperdapat dari soal dengan tingkat kesulitan menganalisis (C4) yang berjumlah 8 butir soal (Tabel 3), dengan rincian bahwa nomor 1, 2, 4, $6,7,8,10$ soal pilihan ganda dan nomor 12 adalah soal dalam bentuk essay. Dari 8 soal yang disajikan, pada tingkatan $\mathrm{C} 4$ seluruh kelas yaitu MS 1, MS 2, MS 3, MS 4 tergolong dalam kategori yang rendah dengan persentase $68,29 \%$. Soal yang memiliki persentase sangat tinggi adalah soal nomor 2 dengan perolehan skor $94 \%$ sedangkan soal dengan persentase terendah dimiliki oleh soal nomor 6 dengan persentase 27,16\%. Pada soal nomor 2 memiliki persentase yang sangat tinggi dikarenakan pada soal ini narasi yang di sajikan tidak terlalu panjang dan di lengkapi dengan grafik yang menyokong data konkrit dari analisis soal. Berdasarkan hasil wawancara dengan siswa tentang soal dengan narasi panjang menunjukkan bahwa siswa merasa kesulitan untuk membaca soal dengan narasi panjang. Sedangkan soal nomor 6 memiliki persentase sangat rendah dikarenakan bentuk soal yang disajikan menuntut siswa untuk menganalisis gambar yang berbeda, sehingga siswa merasa kesulitan dan kebingungan terhadap fakta soal dan konsep materi yang disajikan.

\section{Analisis Data Soal Ranah Kognitif Tingkat C5 (Mengevaluasi)}

Hasil yang diperdapat dari perhitungan soal dengan tingkat kesulitan $\mathrm{C} 5$ atau mengevaluasi berjumlah 3 soal yang berada pada soal nomor 9 , 11, dan 13. Untuk menafsirkan skor nilai yang diperoleh melalui perhitungan atau tes tersebut, maka untuk mendapatkan persentasenya disesuaikan dengan kriteria yang disajikan dalam bentuk Tabel.

Tabel 2. Persentase Analisis HOTS siswa pada soal C5

\begin{tabular}{|c|c|c|c|c|c|c|c|c|c|}
\hline \multirow{3}{*}{ No } & \multirow{3}{*}{ Kelas } & \multicolumn{6}{|c|}{ Soal } & \multirow{3}{*}{$\bar{x}$} & \multirow{3}{*}{$\begin{array}{c}\text { Kategori } \\
\text { Soal }\end{array}$} \\
\hline & & \multicolumn{2}{|c|}{9} & \multicolumn{2}{|c|}{11} & \multicolumn{2}{|c|}{13} & & \\
\hline & & $\mathbf{F}$ & $\%$ & $\mathbf{F}$ & $\%$ & $\mathbf{F}$ & $\%$ & & \\
\hline 1 & XI MS 1 & 14 & 56 & 12 & 48 & 15 & 40 & $48 \%$ & $\begin{array}{l}\text { Sangat } \\
\text { Rendah }\end{array}$ \\
\hline 2 & XI MS 2 & 5 & 20,83 & 4 & 16,66 & 15,5 & 41,33 & $26,27 \%$ & $\begin{array}{l}\text { Sangat } \\
\text { Rendah }\end{array}$ \\
\hline 3 & XI MS 3 & 2 & 8 & 9 & 36 & 17 & 45,33 & $29,78 \%$ & $\begin{array}{l}\text { Sangat } \\
\text { Rendah }\end{array}$ \\
\hline 4 & XI MS 4 & 6 & 24 & 8 & 32 & 13 & 34,66 & $30,22 \%$ & $\begin{array}{l}\text { Sangat } \\
\text { Rendah }\end{array}$ \\
\hline \multicolumn{2}{|c|}{ Rata-rata } & \multicolumn{2}{|c|}{$27,20 \%$} & \multicolumn{2}{|c|}{$33,16 \%$} & \multicolumn{2}{|c|}{$40,33 \%$} & $33,56 \%$ & \\
\hline \multicolumn{2}{|c|}{ Kategori } & \multicolumn{2}{|c|}{$\begin{array}{l}\text { Sangat } \\
\text { rendah }\end{array}$} & \multicolumn{2}{|c|}{ Sangat rendah } & \multicolumn{2}{|c|}{$\begin{array}{l}\text { Sangat } \\
\text { Rendah }\end{array}$} & $\begin{array}{l}\text { Sangat } \\
\text { rendah }\end{array}$ & \\
\hline
\end{tabular}


Tabel 3. Persentase Analisis HOTS siswa pada soal C4

\begin{tabular}{|c|c|c|c|c|c|c|c|c|c|c|c|c|c|c|c|c|c|c|c|}
\hline \multirow{3}{*}{ No } & \multirow{3}{*}{ Kelas } & \multicolumn{16}{|c|}{ Soal } & \multirow[t]{3}{*}{$\bar{x}$} & \multirow{3}{*}{ Kategori soal } \\
\hline & & \multicolumn{2}{|c|}{1} & \multicolumn{2}{|c|}{2} & \multicolumn{2}{|c|}{4} & \multicolumn{2}{|c|}{6} & \multicolumn{2}{|c|}{7} & \multicolumn{2}{|c|}{8} & \multicolumn{2}{|c|}{10} & \multicolumn{2}{|c|}{12} & & \\
\hline & & $\mathrm{F}$ & $\%$ & $\mathrm{~F}$ & $\%$ & $\mathrm{~F}$ & $\%$ & $\mathrm{~F}$ & $\%$ & $\mathrm{~F}$ & $\%$ & $\mathrm{~F}$ & $\%$ & $\mathrm{~F}$ & $\%$ & $\mathrm{~F}$ & $\%$ & & \\
\hline 1 & $\mathrm{XIMS} * 1$ & 25 & 100 & 25 & 100 & 21 & 84 & 5 & 20 & 20 & 80 & 15 & 60 & 19 & 76 & 16,5 & 33 & $69,13 \%$ & Rendah \\
\hline 2 & XI MS 2 & 22 & 91,7 & 24 & 100 & 24 & 100 & 4 & 16,7 & 21 & 87,5 & 17 & 70,8 & 4 & 16,7 & 18,5 & 38,5 & $65,23 \%$ & $\begin{array}{l}\text { Sangat } \\
\text { rendah }\end{array}$ \\
\hline 3 & XI MS 3 & 23 & 92 & 24 & 96 & 25 & 100 & 10 & 40 & 24 & 96 & 23 & 92 & 14 & 56 & 17,5 & 35 & $75,87 \%$ & Sedang \\
\hline 4 & XI MS 4 & 19 & 76 & 20 & 80 & 21 & 84 & 8 & 32 & 19 & 76 & 16 & 64 & 15 & 60 & 8 & 16 & $61 \%$ & Sangat rendah \\
\hline \multicolumn{2}{|c|}{ Rata-rata } & \multicolumn{2}{|c|}{$89,91 \%$} & \multicolumn{2}{|c|}{$94 \%$} & \multicolumn{2}{|c|}{$92 \%$} & \multicolumn{2}{|c|}{$27,16 \%$} & \multicolumn{2}{|c|}{$84,87 \%$} & \multicolumn{2}{|c|}{$71,70 \%$} & \multicolumn{2}{|c|}{$52,16 \%$} & \multicolumn{2}{|c|}{$30,64 \%$} & $68,29 \%$ & \\
\hline \multicolumn{2}{|c|}{ Kategori } & \multicolumn{2}{|c|}{ Tinggi } & \multicolumn{2}{|c|}{$\begin{array}{c}\text { Sangat } \\
\text { tinggi }\end{array}$} & \multicolumn{2}{|c|}{$\begin{array}{c}\text { Sangat } \\
\text { tinggi }\end{array}$} & \multicolumn{2}{|c|}{$\begin{array}{l}\text { Sangat } \\
\text { Rendah }\end{array}$} & \multicolumn{2}{|c|}{ Tinggi } & \multicolumn{2}{|c|}{ Rendah } & \multicolumn{2}{|c|}{$\begin{array}{l}\text { Sangat } \\
\text { rendah }\end{array}$} & \multicolumn{2}{|c|}{$\begin{array}{l}\text { Sangat } \\
\text { Rendah }\end{array}$} & Rendah & \\
\hline
\end{tabular}

*MS: Math Sains

Berdasarkan Tabel 2, secara keseluruhan soal dengan tingkat kesulitan C5 atau mengevaluasi tergolong dalam kategori yang sangat rendah dengan persentase 33,56\% pada MS 1, MS 2, MS 3, dan MS 4. Dari 3 soal yang disajikan dengan kesulitan $\mathrm{C} 5$, soal dengan persentase tertinggi terletak pada soal nomor 13, dikarenakan soal yang disajikan hanya memiliki satu permasalahan, kemudian permasalahan yang di sajikan adalah permasalahan yang sering terjadi dan narasi pada soal tidak panjang sehingga siswa mampu menjawab dengan menghubungkan fakta soal dengan konsep pembelajaran.

Sedangkan pada soal nomor 9 memiliki persentase yang paling rendah dikarenakan soal yang disajikan membuat siswa ragu terhadap fakta soal dengan konsep pembelajaran. Soal yang disajikan menuntut siswa untuk dapat menilai alasan yang tepat dengan permintaan pertanyaan yang disajikan. Berdasarkan wawancara dengan siswa, siswa merasa tertipu dengan pilihan jawaban yang telah disajikan, karena siswa hanya menghubungkan jawaban dengan konsep pembelajaran tanpa melihat kesesuaian jawaban dengan soal.

\section{Analisis Data Soal Ranah Kognitif Tingkat C6 ( Mencipta)}

Data yang diperoleh dari analisis soal berkategori HOTS dengan tingkat kesulitan mencipta (C6) dengan jumlah 2 butir soal, terletak pada nomor 3 dan 5 . Mencipta merupakan tingkat HOTS tertinggi yang dimulai dari $\mathrm{C} 4, \mathrm{C} 5$, dan $\mathrm{C} 6$. 
Tabel 4. Persentase Analisis HOTS Siswa pada soal C6

\begin{tabular}{|c|c|c|c|c|c|c|c|}
\hline \multirow{3}{*}{ No } & \multirow{3}{*}{ Kelas } & \multicolumn{4}{|c|}{ Soal } & \multirow{3}{*}{$\bar{x}$} & \multirow{3}{*}{ Kategori soal } \\
\hline & & \multicolumn{2}{|c|}{3} & \multicolumn{2}{|c|}{5} & & \\
\hline & & $\mathbf{F}$ & $\%$ & $\mathbf{F}$ & $\%$ & & \\
\hline 1 & XI MS 1 & 17 & 68 & 5 & 20 & $44 \%$ & Sangat rendah \\
\hline 2 & XI MS 2 & 18 & 75 & 4 & 16 & $45,50 \%$ & Sangat rendah \\
\hline 3 & XI MS 3 & 17 & 68 & 10 & 40 & $54 \%$ & Sangat rendah \\
\hline 4 & XI MS 4 & 21 & 84 & 8 & 32 & $58 \%$ & Sangat rendah \\
\hline \multicolumn{2}{|c|}{ Rata-rata } & \multicolumn{2}{|c|}{$73,75 \%$} & \multicolumn{2}{|c|}{$27 \%$} & $50,37 \%$ & \\
\hline \multicolumn{2}{|c|}{ Kategori } & \multicolumn{2}{|c|}{ Rendah } & \multicolumn{2}{|c|}{ Sangat Rendah } & Sangat rendah & \\
\hline
\end{tabular}

Berdasarkan Tabel 4, secara keseluruhan soal dengan tingkat 66 tergolong dalam kategori sangat rendah dengan persentase $50,37 \%$ dari 4 kelas yaitu MS 1, MS 2, MS 3, MS 4. Dari 2 soal dengan tingkat kesulitan $\mathrm{C} 6$, soal yang paling tinggi persentasenya terletak pada soal nomor 3 dan yang paling rendah persentasenya adalah pada soal nomor 5 . Persentase soal nomor 3 lebih tinggi didibandingkan soal nomor 5 dikarenakan soal nomor 3 merupakan pertanyaan yang tujuan dari pertanyaan tersebut sudah jelas yaitu siswa dituntut untuk merumuskan tentang konsep materi kapasitas vital paru-paru seseorang setelah dan sebelum melakukan aktifitas, sedangkan pada nomor 5, siswa dituntut untuk memahami maksud soal, menghubungkan permasalahan pada soal, dan membuat hipotesis yang ada pada pilihan jawaban.

Tabel 5. Persentase Analisis HOTS Siswa SMAN Plus Prov.Riau

\begin{tabular}{cccc}
\hline No & Tingkat soal & Persentase & Kategori \\
\hline 1 & C4 & $68,29 \%$ & Rendah \\
2 & C5 & $33,56 \%$ & Sangat rendah \\
3 & C6 & $50,37 \%$ & Sangat rendah \\
\hline Rata-rata & & $\mathbf{5 0 , 7 4 \%}$ & \\
Kategori & & Sangat rendah & \\
\hline
\end{tabular}

Secara keseluruhan HOTS siswa kelas XI SMAN Plus Prov. Riau berada dalam kategori yang sangat rendah atau dengan persentase 50,74\%. Berdasarkan masing- masing soal, untuk soal dengan level $\mathrm{C} 4$ berada pada kategori rendah atau $68,29 \%$, sedangkan soal dengan level C5 dan C6 berada pada kategori sangat rendah atau 33,56\% dan $50,37 \%$.

Data yang dibahas dalam penelitian ini diperoleh dari soal berkategori HOTS dalam ulangan harian pada materi sistem pernapasan kelas XI MS SMAN Plus Prov. Riau tahun ajaran 2018/2019. Secara keseluruhan HOTS siswa tergolong sangat rendah dengan persentase $50,74 \%$. Soal tingkat kesulitan C4 (Menganalisis) merupakan persentase HOTS tertinggi yaitu $68,29 \%$, sedangkan persentase terendah terdapat pada soal C5 (Mengevaluasi) dengan persentase $33,71 \%$.

\section{Soal Ranah Kognitif Tingkat C4}

Berdasarkan data yang diperoleh dari instrumen penelitian yaitu soal atau tes, soal dengan ranah kognitif C4 memiliki persentase tertinggi dibandingkan dengan ranah kognitif C5 dan C6 dan termasuk ke dalam kategori rendah pada keterampilan berpikir tingkat tinggi siswa kelas XI MS SMAN Plus Prov. Riau. Secara keseluruhan terdapat $68,29 \%$ yang mampu menjawab soal dengan benar, sedangkan 31,79\% tidak mampu menjawab pertanyaan dengan benar. Persentase paling tinggi ditunjukkan oleh soal nomor 2 dengan persentase $94 \%$ dengan kategori 
sangat tinggi dan persentase paling rendah ditunjukkan oleh soal nomor 6 dengan persentase sebesar $27,16 \%$ dengan kategori sangat rendah. Dari hasil wawancara dengan siswa, secara keseluruhan persentase yang didapat dari pengolahan data yaitu rendah dengan perbedaan yang signifikan pada masing-masing soal menunjukkan bahwa siswa mengalami kesulitan pada saat mengerjakan soal dengan permasalahan yang disediakan dalam bentuk narasi panjang sehingga siswa dapat dikatakan kurang mampu untuk berpikir kreatif dan kritis. Berdasarkan wawancara dengan guru Biologi, hal ini terjadi karena guru belum secara maksimal memberikan soal yang mengukur HOTS dan memberikan soal berbentuk narasi ataupun kasus sehingga siswa merasa kesulitan untuk mengerjakan soal dalam bentuk HOTS.

Diperkuat penelitian Asdar et al. (2016) bahwa pencapaian indikator-indikator pada Taksonomi Bloom proses kognitif menganalisis pada dimensi pengetahuan konseptual siswa kelas VIII SMP Negeri 5 Sinjai Selatan untuk subjek berkemampuan tinggi cenderung mampu memunculkan indikator menunjukkan hubungan antar variabel, subjek berkemampuan sedang cenderung mampu memunculkan indikator menunjukkan hubungan antar variabel sedangkan subjek berkemampuan rendah cenderung mampu memunculkan indikator mengaitkan. Sedangkan pencapaian indikator- indikator pada Taksonomi Bloom deskripsi proses kognitif menganalisis pada dimensi pengetahuan prosedural siswa kelas VIII SMP Negeri 5 Sinjai Selatan untuk subjek berkemampuan tinggi cenderung mampu memunculkan indikator memerinci, subjek berkemampuan sedang cenderung mampu memunculkan indikator memerinci sedangkan subjek berkemampuan rendah cenderung tidak mampu me munculkan indikator memerinci. Artinya siswa SMAN Plus Prov. Riau belum mampu dalam menganalisis secara rinci maksud dari pertanyaan soal yang tersedia, hal ini disebabkan karena guru jarang membawa siswa beljara pada tahap menganalisis.

Menurut Daryanto ( 2012:110) kemampuan analisis seseorang dituntut untuk dapat menguraikan suatu situasi atau keadaan tertentu kedalam unsur-unsur atau kompenen-kompenen pembentuknnya sehingga situasi atau keadaan menjadi jelas. Soal berkategori C4 dapat dibuat dengan dua bentuk soal yaitu soal berbentuk pilihan ganda dan soal essay. Maka, guru dituntut untuk membuat soal dengan narasi atau cerita sesuai dengan fakta yang ada di lapangan yang berkaitan dengan materi bukan hanya dikutip dari buku ajar atau catatan. Ditambahkan Arikunto ( 2012: 132) soal pada ranah menganalisis adalah soal yang menuntut kemampuan siswa untuk menguraikan atau menganalisis suatu persoalan untuk diketahui bagian-bagiannya.

\section{Soal Ranah Kognitif Tingkat C5}

Soal dengan ranah kognitif C5 tergolong dalam kategori sangat rendah pada keterampilan berpikir tingkat tinggi (HOTS) siswa SMAN Plus Prov. Riau. Secara keseluruhan terdapat 33,56\% siswa yang mampu menjawab dengan benar pada tingatan C5, sedangkan 66,44\% siswa tidak mampu menjawab soal $\mathrm{C} 5$ dengan benar. Persentase paling tinggi ditunjukkan oleh soal nomor 13 dengan persentase $40,33 \%$ dengan kategori sangat rendah dan soal nomor 9 dengan persentase 27,20\% dengan kategori sangat rendah. Berdasarkan hasil wawancara dengan siswa, sangat rendahnya persentase siswa dalam mengerjakan soal C5 karena siswa merasa sulit untuk menghubungkan fakta soal dengan konsep pembelajaran, memeriksa dan menilai pilihan jawaban yang homogen. Soal yang disediakan menunjukkan bahwa siswa dituntut mampu menilai dan memutuskan analisis terhadap permintaan soal. Berdasarkan wawancara dengan guru Biologi, guru belum secara maksimal memberikan soal-soal yang berkategori C5 atau mengevaluasi. Sehingga siswa belum terbiasa untuk mengerjakan soal yang berkategori $\mathrm{C} 5$.

Diperkuat penelitian Arti dan Hariyatmi( 2015) bahwa kemampuan guru mata pelajaran biologi dalam membuat soal HOTS di SMA Negeri 1 Wonosari, klaten sangat buruk dengan persentase $15,2 \%$ pada pembuatan soal $\mathrm{C} 4,3,0 \%$ pada pembuatan soal $\mathrm{C5}$, dan 3,0\% pada pembuatan soal C6. Artinya, siswa SMAN Plus memiliki kemampuan mengevaluasi yang sangat rendah dikarenakan guru jarang membawa siswa pada proses pembelajaran untuk memberikan penilaian terhadap gagasan, prosedur, dal lain-lain. Hal ini 
selaras dengan pendapat Basuki dan Hariyanto (2014: 14) bahwa pada soal C5 jenjang menilai, siswa mampu memberikan penilaian terhadap solusi, gagasan, metodologi, prosedur kerja, dan lain-lain dengan mengunakan kriteria atau standar yang ada untuk menghasilkan nilai manfaat dan efektivitasnya.

Menurut Arikunto ( 2012: 133) bahwa soal evaluasi selalu didahului kasus yang ditelaah oleh siswa dengan teropong hukum, prinsip, dan kemudian melakukan penilaian baik atau tidak berdasarkan benar dan salah. Di tambahkan oleh Daryanto (2012: 113) kemampuan evaluasi adalah menciptakan kondisinya sedemikian rupa sehingga siswa mampu mengembangkan kriteria, standar atau ukuran untuk mengevaluasi sesuatu. Menurut Nugroho (2018:31) level mengevalausi merupakan kemampuan dalam mengambil keputusan berdasarkan kriteria-kriteria tertentu. Ditambahkan oleh Yen dan Halili (2015) HOTS adalah proses internal yang berkembang seiring waktu. Siswa perlu mencerminkan, mengartikulasikan, membenarkan, berinteraksi, mendiskusikan, mempertanyakan, dan lain-lain dalam satu waktu.

\section{Soal Ranah Kognitif Tingkat C6}

Soal dengan tingkat kognitif C6 atau mencipta tergolong kedalam kategori rendah pada keterampilan berpikir tingkat tinggi sesuai dengan KKM yang dibuat oleh sekolah. Secara keseluruhan terdapat 50,37\% siswa yang mampu menjawab pertanyaan dengan benar, dan 49,63\% siswa lainnya tidak mampu menjawab pertanyaan dengan benar. persentase paling tinggi pada soal ini adalah pada soal nomor 3 dengan persentase $73,73 \%$ yang tergolong dalam kategori rendah dan yang paling rendah ditunjukkan pada soal nomor 5 dengan persentase $27 \%$ dan tergolong dalam kategori sangat rendah. Berdasarkan hasil wawancara , siswa merasa kesulitan mengerjakan soal C6, dikarenakan siswa kurang mampu memahami permasalahan yang terjadi pada soal dan siswa juga selalu ragu menjawab pertanyaan karena pilihan jawaban yang homogen atau saling berdekatan. Namun, analisis data menunjukkan bahwa siswa sudah mampu mengerjakan soal dengan kategori C6 dibandingkan C5 dikarenakan soal yang disajikan dalam kategori C6 menuntut siswa untuk merumuskan hipotesis dari permasalahan yang di paparkan pada soal, sejatinya dalam proses pembelajaran siswa sudah memahami maksud dari hipotesis dan siswa sudah pernah merumuskan hipotesis. Berdasarkan hasil wawancara dengan guru Biologi, soal dengan kategori C6 sudah pernah diberikan namun belum secara maksimal atau jarang. Karena guru masih konsisten memberikan soal yang berasal dari bank soal, sehingga siswa kurang mampu berkreasi dalam menghubungkan permasalahan soal.

Diperkuat dengan penelitian Ardhana ( 2017) menyatakan bahwa keterampilan mencipta di kelas VIII D SMPN 02 Baki Sukoharjo sebesar 0\% atau tergolong sangat rendah. Penelitian Sobirin et al. (2016) menyatakan hanya 12 , 5\% siswa yang berhasil sampai pada level C6 pada materi optik. Hal tersebut, menunjukkan bahwa kemampuan berpikir tingkat tinggi siswa untuk mata pelajaran Biologi dan Fisika. Artinya siswa SMAN plus belum mampu membuat hipotesis yang tepat sesuai dengan jawaban yang diinginkan dari soal yang dibuat karena guru jarang membawa siswa belajar pada tahap mencipta (C6).

Menurut Nugroho ( 2018: 39) soal mencipta menuntut siswa untuk dapat mengorganisasi berbagai informasi mengunakan cara atau strategi baru atau berbeda dari biasanya. Siswa dilatih memadukan bagian-bagian untuk membentuk sesuatu yang baru, koheren, dan orisinal. Kemampuan berpikir kreatif atau inovatif yang diuji dalam kemampuan mencipta (C6).

Hasil yang diperoleh dari penelitian tentang Higher Order Thinking Skills (HOTS) siswa kelas XI MS SMAN Plus Prov. Riau pada tahun ajaran 2018/2019 pada materi sistem pernapasan tergolong sangat rendah. Persentase keseluruhan dari tingkatan kognitif C4, C5, dan C6 adalah $50,74 \%$. Persentase tertinggi berada pada kategori C4 dengan persentase $68,29 \%$ dan persentase terendah berada pada kategori soal C5 dengan persentase $33,56 \%$. Hal ini sejalan dengan penelitian Yusmanto et al. (2017) menuliskan bahwa dari jawaban tes yang diberikan kepada siswa yang dianalisis secara deskriptif. Tingkatan HOTS meliputi rendah, sedang, dan tinggi. Hasil penelitian pada ranah kognitif menganalisis sebesar $5,42 \%$ (sedang), mengevaluasi sebesar 5,50\% (sedang), mencipta sebesar $4,50 \%$ (rendah). HOTS 
siswa secara umum berada pada kriteria sedang. Disarankan pada penelitian selanjutnya untuk mengkaji HOTS pada proses aktivitas belajar kaitannya terhadap transfer pengetahuan dan retensi pengetahuan yang diterima siswa. Hal ini sesuai dengan penelitian siswa SMAN Plus Prov. Riau memiliki keterampilan berpikir tingkat tinggi yang sangat rendah dalam pelajaran biologi.

Selanjutnya Shidiq et al. (2015) menuliskan bahwa Subjek dalam penelitian ini adalah 95 siswa terdiri dari 3 kelas yang memiliki nilai rata-rata kelas tinggi, sedang, dan rendah. Berdasarkan hasil penelitian yang telah dilakukan kesimpulan yang didapatkan adalalah sebanyak 7,4\% siswa memiliki keterampilan berpikir tingkat tinggi sangat rendah, $25,2 \%$ rendah, $52,7 \%$ sedang dan $14,7 \%$ tinggi. Menunjukan bahwa keterampilan berpikir tingkat tinggi siswa masih di bawah rata-rata.

Selanjutnya menurut Gais dan Afriansyah (2017) mengungkapkan bahwa siswa dikategorikan mampu menyelesaikan soal-soal high order thinking. Faktor-faktor yang menyebabkan siswa keliru dalam menyelesaikan soal-soal high order thinking diantaranya adalah kurang teliti dalam proses pengerjaan soal, kemampuan awal matematis siswa yang rendah, proses yang dilalui selama pembelajaran tidak maksimal, kurangnya pemahaman siswa terhadap soal, ketidaklengkapan dalam membaca soal dan kurangnya perhatian dari orang tua. Menunjukan siswa mampu mengerjakan soal-soal HOTS.

Kemudian Laili dan Wisudawati (2015) menunjukan bahwa mayoritas soal UN Kimia pada tahun ajara 2011/2012 (92,5\%) dan 2012/2013 (85\%) menuntut keterampilan berpikir tingkat rendah siswa. Keterampilan berpikir tingkat tinggi yang diujikan pada soal-soal tersebut hanya mewakili jenjang kognitif menganalisis. Hal ini serupa dengan hasil penelitian SMAN Plus Prov. Riau dengan kategori rendah pada tingkatan menganalisis.

Menurut Elyana et al. (2017) menuliskan bahwa persentase soal Fisika 2016 berkategori HOTS yang dianalisis menggunakan indikator soal menurut A.Thomas dan G. Thorne serta data analisis kemampuan berpikir tingkat tinggi siswa pada soal ujian nasional fisika yang diperoleh melalui jawaban siswa dalam mengerjakan soal. Berdasarkan analisis data dapat disimpulkan bahwa soal ujian nasional fisika mampu mengukur kemampuan berpikir tingkat tinggi siswa yang ratarata dikategorikan kurang baik. Hal ini menunjukkan kemampuan berpikir tingkat tinggi siswa di bawah rata-rata.

Selanjutnya penelitian Rochman dan Hartoyo (2018) menunjukan bahwa Uji coba valiadasi secara empiris dilaksanakan oleh 95 siswa. Jumlah siswa yang diukur menggunakan total sampling sebanyak 148 siswa kemampuan menganalisis sangat tinggi 1 siswa atau $0,5 \%$, kemampuan menganalisis tinggi 59 siswa atau 40\%, kemampuan menganalisis sedang 62 siswa atau $42 \%$, kemampuan menganalisis rendah 25 siswa atau $17 \%$, kemampuan menganalisis sangat rendah 1 siswa atau 0,5\%. Secara rata-rata dapat disimpulkan bahwa HOTS pada taksonomi menganalisis siswa termasuk dalam kriteria sedang.

\section{KESIMPULAN}

Berdasarkan hasil penelitian yang sudah dilakukan tentang kemampuan berpikir tingkat tinggi siswa SMAN Plus Prov. Riau, maka dapat disimpulkan bahwa kemampuan berpikir tingkat tinggi (HOTS) siswa kelas XI MS SMAN Plus Prov. Riau dalam mengerjakan soal C4 tergolong rendah dengan persentase $68,29 \%$ kemudian C5 dan C6 tergolong sangat rendah dengan persentase masing-masing $33,56 \%$ dan 50,37\%. Sehingga kemampuan berpikir tingkat tinggi (HOTS) siswa kelas XI MS SMAN Plus Prov. Riau dalam mengerjakan soal ulangan harian masih tergolong sangat rendah dengan persentase $50,74 \%$.

\section{DAFTAR PUSTAKA}

Afriyanti, I., Wardono.,\& Kartono. 2018. Pengembangan Literasi Matematika Mengacu PISA Melalui Pembelajaran Abad Ke-21 Berbasis Teknologi. Prosiding Seminar Nasional Matematika 2018. HIm. 609. ( Diunduh 5 Desember 2018, Rabu, 21.00 Wib).

Ardhan, T. 2017. Keterampilan Berpikir Siswa dalam Menyelesaikan Soal Garis dan Sudut Berdasarkan Taksonomi Revisi. Abstrak Hasil Penelitian Universitas Muhamadiyah Surakarta. Surakarta. (Diunduh 27 April 2019, Sabtu, Pukul 13,09 WIB)

Arifin, Z. 2014. Evaluasi Pembelajaran. Bandung: Remaja Rosdakarya. 
Arikunto, S. 2012. Dasar-Dasar Evaluasi Pendidikan. Jakarta: Bumi Aksara.

Asdar, M., Nurdin, S dan Suradi, T. 2016. Deskripsi Pemahaman Materi Sistem Persamaan Linear Dua Variabel Ditinjau dari Dimensi Proses Kognitif Mneganalisis dan Dimensi Pengetahuan Konseptual dan Prosedural Revisi Taksonomi Bloom pada Siswa Kelas VIII SMPN 5 Sinjai Selatan. Makasar. (Diunduh, 27 April 2019, Sabtu, Pukul 13,09 WIB).

Arti, E.P.N \& Hariyatmi. 2015. Kemampuan Guru Mata Pelajaran Biologi dalam Pembuatan Soal HOT (Higher Order Thinking) di SMA Negeri 1 Wonosari Klaten. Seminar Nasional XII Pendidikan Biologi FKIP UNS 2015. HIm. 387. Universitas Negeri Semarang. ( Diunduh 5 Oktober 2018, Jum'at, 05.45 WIB).

Basuki, I \& Hariyanto. 2014. Asesmen Pembelajaran. Bandung: Remaja Roasdakarya.

Daryanto. 2012. Evaluasi Pendidikan. Jakarta: Rineka Cipta.

Elyana, Fakhruddin, \& Yunita.2017. Analisis Higher Order Thingking Skills ( HOTS) Siswa MAN 2 Model Pekanbaru Dalam Menyelesaikan Soal Ujian Nasional Fisika Tingkat SMA/MA. HIm. 1-9. ( Diunduh 21 September 2018, Jum'at, 21.40 WIB).

Gais, Z \& Afriansyah, E.A. 2017. Analisis Kemampuan Siswa dalam Menyelesaikan Soal Higher Order Thinking Ditinjau dari Kemampuan Awal Matematis Siswa. Jurnal "Mosharafa", Volume 6, Nomor 2, Mei 2017. STKIP Jakarta. ( Diunduh 21 September 2018, Jum'at, 21.40 WIB).

Kemendikbud, 2017. Pengembangan Soal HOTS. Direktorat Pembinaan Sekolah Dasar.

Laili, N., R., dan Wisudawati, A.W. 2015. Analisis Soal Tipe Higher Order Thinking Skills (HOTS) dalam soal UN Kimia SMA Rayon B Tahun 2012/2013. Jurnal Karunia. (Nomor 1 Tahun 2015). HIm. 28-39. ( Diunduh 25 November 2018, Minggu, 06.05 WIB).

Munthe, A.P. 2015. Pentingnya Evaluasi Program Di Institusi Pendidikan: Sebuah Pengantar, Pengertian, Tujuan dan Manfaat. Scholaria, Vol. 5, No. 2, Mei 2015. HIm. 1 - 14. FKIP Universitas Pelita Harapan. ( Diunduh 23 Agustus 2018, Kamis, 19.30 WIB).

Nugroho, A.R. 2018. Higher Order Thinking Skills (HOTS). Jakarta: Gramedia Widiasiarana Indonesia.

Rohman, S \& Hartoyo, Z. 2018. Analisis higher order thingking skills (HOTS) Taksonomi menganalisis permasalahan fisika. Science and physics education journal (SPEJ).
Volume. 1, No. 2, Juni 2018. (Diunduh 11 Oktober 2018, Jum'at, 07.06, WIB).

Saat, S. 2015. Faktor-Faktor Determinan dalam Pendidikan. Jurnal Al-Ta'dib. Vol. 8 No. 2, Juli-Desember 2015. HIm. 1. FKIP UIN Sunan Alauddin Makassar

Shidiq, A.S., Masyukuri, M. \& Susanti, E. 2015. Analisis Higher Order Thinking Skills (HOTS) Menggunakan Instrumen Two-Tier Multiple Choice pada Materi Kelarutan dan Hasil Kelarutan untuk Siswa Kelas XI SMA N I Surakarta. Prosiding Seminar Pendidikan Sains. ISSN: 2407-4659, November 2015. HIm. 159. ( Diunduh 17 September 2018, Selasa, 06.30 WIB).

Sobirin, M., Koes, S.\& Kusairi, S. 2016. Level Keterampilan Berpikir Siswa Pada Materi Optik. Prosiding Seminar Nasional Pendidikan IPA Pascsarjana UM, Vol. 1,2016, ISBN: 978-602-9268-21-2. HIm. 373. (Diunduh 19 Agustus 2018, Minggu, 08.15 WIB).

Sugiyono. 2015. Metode Penelitian Pendidikan: Pendekatan Kuantitatif, Kualitatif, dan R\&D. Bandung: Alfabeta.

Widiawati, L., Joyoatmojo, S., \& Sudiyanto. 2018. Higher Order Thinking Skills (HOTS) Pada Pembelajaran Abad 21. Prosiding Seminar Nasional Hasil Penelitian Pendidikan Dan Pengajaran. Volume. 4, No. 1, April 2018. ( Diunduh 21 Agustus 2018, Selasa, 08.20 WIB).

Wulandari, N \& Sholihin, H. 2016. Analisis Kemampuan Literasi Sains Pada Aspek Pengetahuan dan Kompetensi Sains SMP pada Materi Kalor. EDUSAINS, Vol. 8 Nomor 01 Tahun 2016. HIm. 67-73. ( Diunduh 19 Agustus 2018, Minggu, 08.15 WIB).

Yen, T.S \& Halili, S.T. 2015. Pengajaran Yang Efektif Untuk Pemikiran Tingkat Tinggi (Hot) dalam Pendidikan. Jurnal Online Pendidikan Jarak Jauh dan e-Learning, April 2015 Volume 3, Edisi 2. ( Diunduk 19 Agustus 2019, Minggu, 08.15 WIB).

Yusmanto, H., Budi E.S. \& Eri, T.D. 2017. Higher Order Thinking Skills Siswa SMPS IT Darul Azhar Berdasarkan Taksonomi Bloom Revisi. HIm. 1-8. (Diunduh 25 November 2017, Minggu, 06.00 WIB). 